\title{
Influence of Social Media on Brand ANd BRANding: A Sociological Review
}

\author{
Rosila Bee Mohd Hussain \\ University of Malaya \\ rosila_bee@um.edu.my
}

\begin{abstract}
Social media is a platform of reflection our society to depicts various views and opinions on how society should live. Social media, either it is printed, electronic or the web helps community stay connected one way or another and even teaching how one should choose a brand. Brand in this article refers to a brand is a permanent mark that is hot-stamped onto a good or service. This article will look into how social media is making an impact of the brand chosen by consumer. This contextual discussion will focus on how social media is seen a platform that could stimulate the thoughts of consumer in choosing and buying certain brand in a sociological view. In discussing the impact of social media and brand, various factors brands familiarity, perception, quality and value will be covered. This article therefore will attempts to relate the contemporary concept of the brand and also how advertising in social media has also changed view on the product descriptions by invoking emotions of consumer and position the brand as representing something more than the product.
\end{abstract}

Keywords: Social media, brand, branding, sociology, consumerism.

\section{INTRODUCTION}

Taking the literal meaning of the word and encompassing it in to a universal business understanding, a brand is a permanent mark that is hot-stamped onto a good or service. According to the American Marketing Association (AMA), a brand is composed of several elements, such as a name, a logo, and a design. It is often that a brand has all of those elements working together in a way that uniquely identifies a company and differentiates it from its competitors.

Therefore, a brand can be a logo, a slogan or catchphrase, a characteristic, etc. A brand is a name that resonates in consumers' minds, and greatly affects their purchasing behavior (Kapferer 2008). It could be said that a brand can act as a verbal and nonwritten mutual agreement between any two parties, such as a producer and a consumer. Keeping in mind the various definitions of a brand, the hot stamping of a permanent mark onto a product or service, is known as branding. A frequently cited epithet is that 'a product is made in a factory; a brand is bought by a customer' (Wang 2008). 
Attention given by media on branding is thus a way of highlighting transformation in the forms, times and spaces of consumer culture. From a sociological perspective, marketization describes the expansion of arrangements for bringing buyers and sellers for self-advantaging exchange. Marketization has intensified in recent years as part of what is sometimes call neoliberalism (Harvey 2005). Due to bigger and better products in the current world, consumers have begun to face an important problem: the increased uncertainty about various products attributes. Consumers tend to asses certain product attributes in a holistically manner rather than a case-by-case basis. Therefore, both extrinsic and intrinsic factors must be accounted when trying to differentiate a product from its competitors. In these circumstances, brands can potentially play many different roles in the consumer decision process.

\section{BRAND AND BRANDING}

The phenomenon that are described as brands are diverse. According to McClintock (1994), in the second half of the nineteenth century, a climate was created within aggressive competition between producers are becoming more intense, due to the stretching of markets over national and international space as well as economic competition between nations. In the early stages of development, brands were intended to allow the producer to speak 'directly' to the consumer through presentation, packaging and other media, a capacity that became increasingly important as markets grew rapidly. However, branding involves not simply a dis-intermediation of the role of the retailer, but also a re-intermediation in the development of brand logos, identities or personalities to speak for the product and to act as a guarantor of quality (Lury 2011).

The historical meaning of the word "brand" is "burn". This word comes from an Old Norse Germanic root or "mark made by hot iron" (Healy 2008:6). It means something being burnt in something, for example customers minds. A brand is a name, design, symbol or other feature that distinguishes one product from another. It is more than just a tangible product or service because it can be packed with the consumer's feelings and perception towards the product. It is a promise to the customer (Kotler \& Armstrong 2010). A great brand can be something the consumer can trust and hang on with when the world around changes. It can reflect you as a person or what you want to be. A brand should provide values, personalities, stories, benefits and slogans for consumers (Malik et.al. 2012).

According to Kronberger (2010), the meaning and purpose of a brand has been changing over the years. It was suggested that it is better to create something like a mind map of what a brand is and might be, instead of trying to find a particular definition for it and establish it as the right one (Kronberger 2010). Kronberger (2010) also suggested that a brand may be defined as media. It means, that brand is a relation between different parties. A brand connects a buyer supplier, final consumer and producer. It connects all the involved parties and delivers brands value.

Due to bigger and better products in the current world, consumers have begun to face an important problem: the increased uncertainty about various products attributes. Consumers tend to asses certain product attributes in a holistically manner rather than a case-by-case basis. Therefore, both extrinsic and intrinsic factors must be accounted when trying to differentiate a product from its competitors. In these circumstances, brands can potentially play many different roles in the consumer decision process. 
According to Romani et.al. (2012), it is shown that consumers' psychological, sociological and economic processes are simultaneously involved in choice behavior. In these days, a product or a service is almost irrelevant without the brand. Often, consumers will tend to choose a brand that they consider congruent with their self-image. In this particular way each consumer at an individual basis will try to reflect his or her own identity through choice. When part of a larger social group, consumer choices tend to converge to a certain pattern thus forming the basics of an individual social identity (Cătălin \& Andreea 2014).

There are various factors identified in choice of brand:

- Brand familiarity - brand familiarity is considered as higher standard of awareness and measure consumer understanding as well as knowledge about the brand. Normally a well-known brand is a source of competitive advantage as familiar brands are highly salient in the minds of consumers, and the brand has the ability to differentiate itself in the clutter of competition When consumers decide to buy products, they tend to be affected by brand familiarity (Chen, Chen \& Wu 2015: Lee, Conroy \& Motion 2012).

- Brand awareness - awareness of the brand refers to the ability to recall, recognize the brand in various situation and link to the brand name, logo, jingles and so on to certain associations in memory. Not only brand awareness is of the main factors to create brand value but also it is a key element influences consumer perceptions and attitudes. To some extent, products that have high level of awareness are likely to result in higher sales because without awareness no communication or transaction will be occurred (Aaker, 1996).

- Brand equity - corporate brand can play an important role and it can represent something beyond merely being known by its products or services. Brand equity composes of 4 assets: Brand awareness, brand association, brand quality and brand loyalty. Brand equity is what makes branded products different from commodity products. To gain brand equity, brands must communicate things such as values, emotions, lifestyle, status; something more than just a product name and functionality (Mohsin 2009).

- Riskperception - if the consumers are familiar with the brand, they perceived less risk. It should be noted that consumers' perceived risk is a crucial determinant in their decision making, especially for intangible and heterogeneous products (Soo-Hyun 2020). Risk encounters during their purchasing and consumption, which have a negative impact on consumer's attitude. In order to avoid that, consumers reduce to buy poor-quality products and instead, prefer to buy more expensive ones (Yusuf, Fatih, \& Hayrettin 2013).

- Price perception - Though lower price products are preferred by most consumers there are other attributes that consumers take in to consideration that is perception of quality and perception of risk. When the price is high, consumers perceive that the quality of the product is high. A consumer-based brand experience and brand preference have important roles in explaining the link between price perception and repurchase intention (Yasri et.al 2020).

- Perceived quality - In consideration to taste and ingredient, consumer perceive less quality in these attributes compared to package and volume. Objective of quality is evaluation of the product based on physical characteristics. While perception of 
quality considers subjective notation, which is consumer evaluation of the product and judgment that based on some attributes. Consumer evaluates the quality in association of extrinsic (color, size, flavor or aroma) and intrinsic (package, price, advertising and peer pressure) cue (Collins \& Lindley 2003).

- Perceived value - Buyers are price seekers - those who look for low price, as a result, for some consumers having inexpensive product means achieving high value. Consumer will be satisfied and or give high value if the quality-price relationship matches their expectation. That is value is low price, value is whatever a consumer wants in the product, value is quality consumer get from the product and value is what consumer get when consumer give. These attributes were summarized and eventually the concept of perceived value is defined as the consumer's overall assessment of the utility of the product based on "what is given" and "what is received" (Zeithaml, 1988).

The elements of branding are surrounding as every day. Branding helps to ensure a good reputation and encourages a loyalty of the customers and ensures the product quality. According to Kotler \& Pfoertsch, (2006), branding is considered to be successfully effective once it incorporates throughout its operations the elements of:

- Consistency - the ability to demonstrate the constant delivering of the brand's promised values via product/service delivery, marketing distribution channels, and even handling customer complaints. To become consistent organizations should leverage this with a holistic approach, far beyond the product or brand. It affects each and every single contact point between the organization and the people.

- Clarity - it is situated upon a company's vision, mission, and values. Clarity makes the brand more tangible and understandable. Clarity is based on the vision, mission, core values and core competencies of the organization. These should be easy to communicate and understand in such a way, that it enables people to position the brand relevance in their mind.

- Continuity - explains that a brand should not only be market driven, but a brand should strive for being a market driver. People trust the brand that it will deliver whatever it promised based on past experience, they know what to expect. Hence continuity is an important principle to develop brand equity and trust on the long term. Stable brands and predictable outputs will contribute significant to risk reduction.

- Visibility - indicates that a brand must always seek to increase its exposure via increasing its target audience base. Brand visibility is all about increasing brand exposure and developing brand awareness.

- Authenticity - meant to stimulate marketers towards original and creative thinking. Brand authenticity is the undisputed origin of behaviorism of all organizational members with the objective of creating the feeling for the customer to own, use or direct a unique valuable product and/or service.

Kotler (2010) explained how branding elements are used as an attribute in order to create a particular association in customers' minds. A successful brad will show, communicate and deliver a benefit of its services and company in general towards customers, partners 
and owners through those elements. The success of a brand depends on the experience that the consumer obtains from it. Diallo and Siqueira (2017) found that prior positive brand experience affects positive and significant to consumer purchase intention. Consumers' positive emotion on the brand can also generate positive feelings on the brand and it can affect their purchase intention (Moreira et al., 2017). In the era of social media, this is becoming even more apparent, when communication is becoming more centered on the consumer.

\section{FRAMEWORK FOR SOCIAL MEDIA INFLUENCE}

In looking further into the discussion on the influence of social media towards brand and branding the Honeycomb model that was developed by Smith in 2007 is used to analyze the use and functionalities of social media. Honeycomb model consists of seven building blocks: identity, conversations, sharing, presence, relationships, reputation, and groups; detail of Honeycomb model can be seen in Figure 1 below (Kietzmann et.al. 2011). Every social media platform does not need to have all seven building blocks.

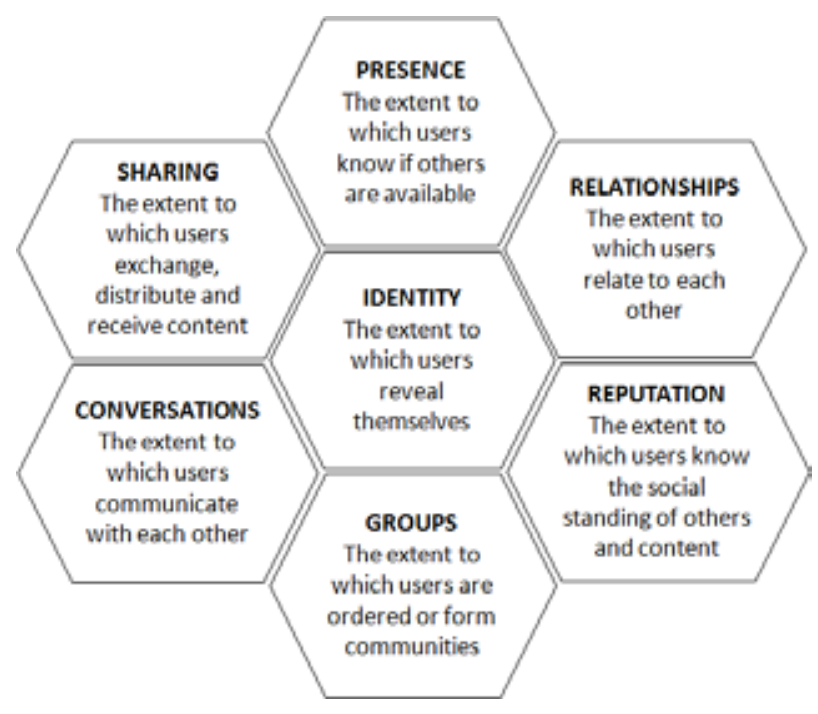

\section{Figure 1: The Honeycomb of Social Media Model (Source: Kietzmann et.al. 2011)}

According to Kietzmann et.al (2011):

- Identity block - represents the extent to which users reveal their identities in a social media setting. This can include disclosing (or withholding) information such as name, age, gender, profession, location, and also information that portrays users in certain ways. People tie different identities to the context of the different social media platforms they use.

- Conversations block - many but not all, social media sites are designed primarily to facilitate conversations among individuals and groups. The conversations block of 
the framework represents the extent to which users communicate with other users in a social media setting. A fundamental implication of conversation are benefits and risks in consumer joining and manipulating conversations.

- Sharing block - represents the extent to which users exchange, distribute, and receive content. The term 'social' often implies that exchanges between people are facilitated by a shared object (e.g., a group on, text, video, picture, sound, link, location. Without these objects, a sharing network will be primarily about connections between people but without anything connecting them together.

- Presence block - represents the extent to which users can know if other users are accessible. It includes knowing where others are, in the virtual world and/or in the real world, and whether they are available. Should users prefer to engage in realtime, then the social media platform should offer a presence or status line indicator, along with a suitable mechanism through which these users can contact each other and interact.

- Relationships block - represents the extent to which users can be related to other users. By 'relate,' it means that two or more users have some form of association that leads them to converse, share objects of sociality, meet up, or simply just list each other as a friend or fan. In the context of Instagram for example, relationship can be built through following each other. An Instagram user could follow certain account to be able to see the updates as well as accept others' follow request to connect with them.

- Reputation block - is the extent to which users can identify the standing of others, including themselves, in a social media setting. However, in social media context, reputation is built upon opinions through electronic word of mouth; if firms receive good electronic word of mouth, their reputation will be increased. Electronic word of mouth is in a form of comments and endorsement by other social media users, followers, and opinion leaders. Reputation also could be seen in numbers in terms of number of likes and followers on Facebook, Twitter, and Instagram as well as number of thumbs up or thumbs down and number of views on YouTube (Kietzmann, Silvestre, McCarthy, \& Pitt, 2012).

- Groups block - represents the extent to which users can form communities and subcommunities. It can be assumed that a social media community would enjoy a way to group its users, even when the number of likely contacts is low for each member initially. However, if a group wants to pursue an agenda and grow its membership, then more formal group rules and functions would be required.

In media theory, the terms 'frame', 'window', 'mirror', 'screen' and 'interface' are used in many discussions of media platform. The most basic definition of frame in media theory is 'a window that opens onto a larger space that is assumed to extend beyond the frame' (Manovich 2001:80). This suggested that brands organize the activities of the market by acting as a dynamic frame or interface for communication (between brand and consumer). Importantly, the communication of the brand is not only to do with price, but also of emotion, or affect, intensity and qualities (Pavitt 2000). 


\section{INFLUENCE OF SOCIAL MEDIA ON BRAND AND BRANDING}

Social media can be defined as any website which allows user to share their content, opinion, views and encourages interaction and community building (Neti 2011). According to Neti (2011), 'social' refers to the communication or interaction of individuals within a group or community and 'media' generally refers to advertising where the communication of ideas or information takes place through publications or channels. Social media has come with a new form of consumer socialization where the peer communication has significant impact on consumer decision making that is social networking. Social networking sites may be an important source of consumer socialization by providing people a virtual space to communicate through the internet (Vinerean, Cetina, Dumitrescu \& Tichindelean 2013).

The social Web is changing the traditional brand communications that were previously controlled and gradually being shaped by consumers. During the social media age, knowledge of both the influence of firm-created communication on consumer perceptions of brands and the influence of consumer online content creation on brands is important (Berthon, Pitt \& Campbell 2008; G. Christodoulides 2009). Social media platforms offer an opportunity for customers to interact with other consumers (Li \& Bernoff 2011).

Social media is now seen as an emerging trend among marketers due to its potential to influence the marketing elements. It is being used for branding purpose extensively. Companies are using social media campaigns to attract the prospects and making the existing customers brand loyal. As the usage of social media is increasing at a fast pace private business firms and government bodies are also using the platforms as communication tools (Kim \& Ko 2012). Consumers are losing their interest from traditional media such as TV, radio, or magazines and are increasingly using social media platforms for searching the information (Mangold and Faulds 2009).

Social media plays an important role in how consumers discover, research, and share information about brands and products. Social media may help to strengthen or change brand image, but in order to benefit from the power of social media, brands need to manage and enact their presence constantly (Pozin 2014). Brands may seek customer acquisitions by taking part in social media activities such as discussions, that promote the brand to be associated with relevant themes and brands whose audiences are similar as the target market. The key to new customer acquisitions is content that is interesting to the users, and participating on discussions on social media as shown in Figure 2.

Visual content may be used to boost user engagement on social media. Posts that include pictures or video are shared more often than content that does not include visual elements. Having well-planned "visual branding strategy benefits companies on social media. Search engines, print media and social media is among the most useful in terms of advertising. Search engines for example show advertising based on keywords while social media advertising allows advertisers to target on specific criteria relevant to social media users' interests. 


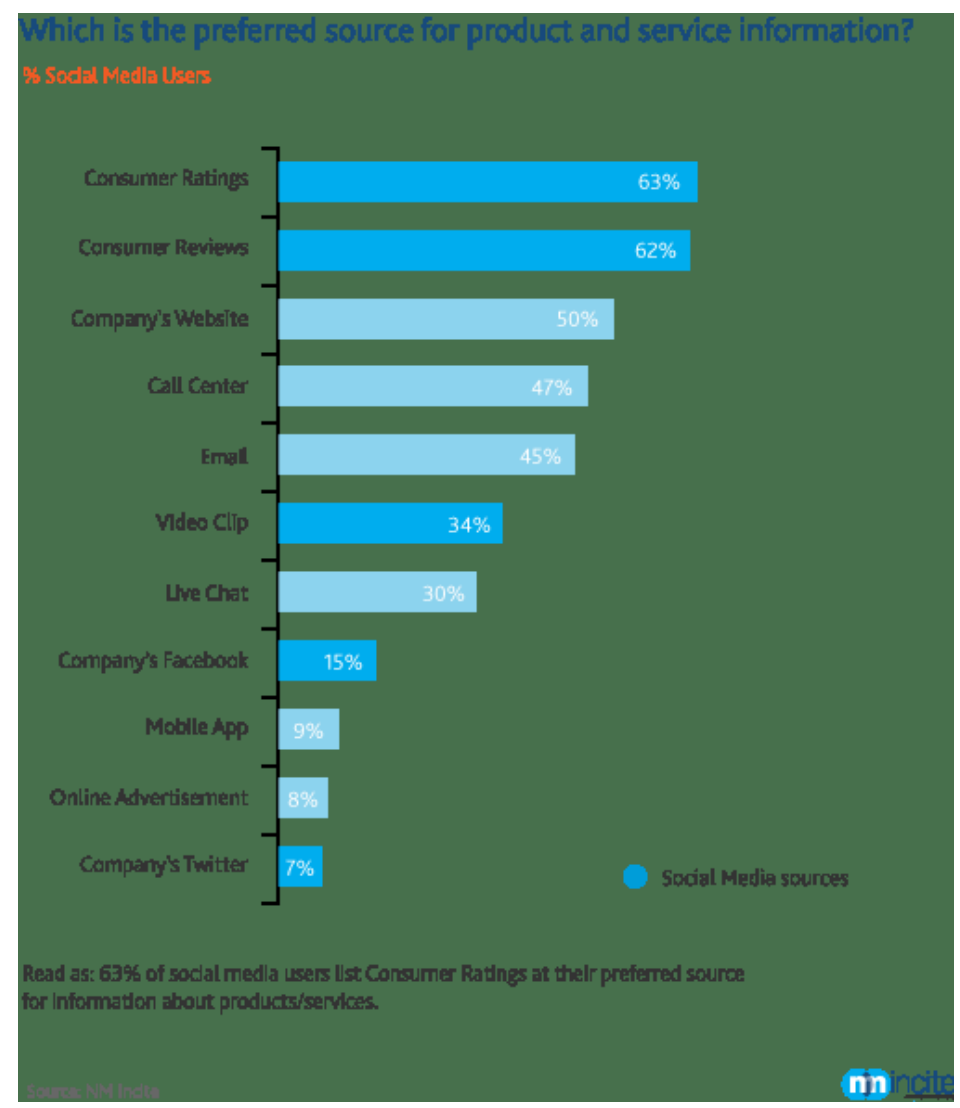

\section{Figure 2: Product and service information preferred by users (Source: Nielsen Media Incite 2011)}

Some of the identified impact of social media on the issue of brand and branding includes:

- Positive effects:

i. Social media consumer advocates - social media platforms are like a megaphone for die-hard customers (Martinez, 2019).

ii. Positive brand and product awareness - this creates an opportunity for a brand or product to shine so make sure the information they see is positive and authentic (Martinez, 2019).

iii. Social media advertising is worth the investment-brands have seen a hugely positive impact of social media advertising and according to Adobe millennials feel that social media is the most relevant ad channel (Martinez, 2019).

iv. Social Media plays a key role in protecting brands - social media users say they write product reviews to protect others from bad experiences, and they share their negative experiences to "punish companies" (Nielsen Media, 2011).

v. Social media helps to increase market insight on various brands - the biggest comfort with the social media is that it helps the businesses in marketing their brand to the wider 'global' community (Kabani \& Brogan, 2010) 
- Negative effects:

i. Negative brand and product awareness - people often discuss brands online do not follow those brands' owned profiles. This is usually because the comments about the brand are negative.

ii. Response time is critical - for certain social media platforms, consumers demand a fast response time for their concerns. $78 \%$ of people who complain to a brand via Twitter expect a response within an hour as reported by Lithium.

iii. The wrong online brand system can fate an organization - put at a tremendous viral social drawback.

\section{BRAND EQUITY AND ADVERTISING}

According to Aaker (1991: 15), brand equity can be defined as "a set of brand assets and liabilities linked to a brand, its name and symbol that add to or subtract from the value provided by a product or service to a firm and/or to that firm's customers". Brand communication positively affects brand equity as long as the message creates a satisfactory customer reaction to the product in question compared to a similar non-branded product (Yoo et.al., 2000).

Advertising plays an important role in today's competitive world by which organizations communicate with their customers, both current and potential. Advertising is the activity of attracting consumer attention. Through advertisement marketers transmit product information, differentiate their products from that of competitors and increase their market share by persuading consumers. For new or niche brand, recognition is important, thus, using advertising is tactical tool to familiarize consumers with new products and create buying incentives. It is a fact that developing a brand is difficult and take times, therefore companies should make use of advertisement as a technique to enter a branded product.

According to Kotler (1988), advertising consists of non-personal forms of communication conducted through paid media under clear sponsorship. He said that the purpose of advertising is to enhance potential buyers' responses to the organization and its offering. Customers are valuable assets for the enterprise, but they can be costly to acquire and retain (Kotler, 1988). Advertising increases buying behavior for those who have a positive attitude and or trust towards advertised products (Mehta 2000). People learn about the product from advertisement. Through advertisement customer associate the product logo with the product (taste, price, value). Sometimes the consumer might switch to other brand because of the repeated advertisements of the other brands (Fill, 2002).

There are a number of factors that influence advertising effectiveness such as brand name prominence, brand image, advertising recall, persuasion, search for information, buying intention and the purchase decision process (Jefkins \& Yadin, 2000). According to Fletcher (1992), no advertiser waits for a year for their advertising to take effect. Advertising must work both quickly and residually and must generate a response both today and tomorrow. Advertising could not possibly work in the future if it does not work in the present

Advertising plays an important role in increasing brand awareness. Advertising is positively concerned with the awareness of the brand association which is increased brand equity. This is crucial to the development of brand equity. Ahmed and Zahid (2014) have demonstrated that social media and internet technologies facilitate the interaction and 
communication between a brand and its customers. They also stated that several brands are now following social networks in order share information about their products and services. Brand equity is will then influence consumer preferences and therefore, building a strong brand has become very important for several organizations as it brings various marketing advantages for them and enhances their competitive strengths (Khan et.al., 2009).

For brands that has suffered a decline in brand loyalty over time, one of the major contributing factors was a lack of advertising support. Therefore, it is very important for company's brand to develop a well-communicated strategy that would help them gain a better brand's position and protecting them from other rivals or competitors (Makasi et.al. 2014).

\section{CONCLUSION}

In light of this discussion, it has look into how social media is making an impact of the brand chosen by consumer. The contextual discussion has shown how social media is seen a platform that could stimulate the thoughts of consumer in choosing and buying certain brand in a sociological view. Increasing use of social media worldwide has led to the belief that this is a valuable tool in supporting consumer engagement. Companies are continually looking to new methods for reaching consumers and for shaping consumer behaviors which include brand loyalty, brand equity and buying intention. Social media platform has created mechanisms for which consumers can develop rapport and create interactions with brandspecific content. Strategic approach by companies requires high degree of maintenance and they should be prepared to manage well their online customer relationships. In discussing the impact of social media and brand, various factors of brands familiarity, perception, quality and has also been discussed. Some of the effects of advertising towards branding issue are includes how advertisement can be responsible for popularizing brands and also creating brand awareness and elicit interest towards a brand. All form of social media has its strength in promoting or demoting a brand. Visual media for example can be very expensive but frequent insertions are required to popularize a brand

The paper concludes by proposing that companies should invest in marketing and branding in order to increase brand awareness, brand visibility, association and perceived quality. Brand familiarity could also be improved through advertisement and promotion to let consumers know that the brand exists. Social media content therefore can be seen as a way to increase consumers' brand awareness and brand attitudes rather than to compete with user-generated social media content. It is proposed that future discussions will expand with other social media platforms coverage including Facebook, twitter, Instagram and others in comparing the effectiveness of each of these social media platforms in increasing brand equity and brand awareness.

\section{REFERENCES:}

Aaker, D. (1991). Managing brand equity. Capitalizing on the value of a brand name. New York: Free Press.

Aaker, D. (1996). Building strong brands. New York: Free Press.

M. A. Ahmed and Z. Zahid, (2014). Role of social media marketing to enhance CRM and brand equity in terms of purchase intention. Journal of Management Research.4 (3), 533-549. 
Berthon, P.R., L. Pitt, \& C. Campbell (2008). Ad Lib: When customers create the ad. California Management Review, 50(4), 6-31.

Christodoulides, G. (2009). Branding in the post-internet era. Marketing Theory, 9(1), 141-144.

Cătălin, M. C. \& Andreea P. (2014). Brands as a mean of consumer self-expression and desired personal lifestyle. Procedia - Social and Behavioral Sciences, 109, 103-107.

Chen, M.R.A., Chen, S. \& Wu, C. (2015). Motivational orientation and brand familiarity: Ppositive emotions and skepticism toward online advertising using the English language. Journal of Literature and Art Studies, 5(4), 282-300.

Collins-Dodd, C., \& Lindley, T. (2003). Store brand and retail differentiation: The influence of store image and store brand attitude on store own brand perceptions. Journal of Retailing and Consumer Services, 10(6), 345-352.

Diallo, M.F., \& Siqueira Jr., JR. (2017). How previous positive experiences with store brands affect purchase intention in emerging countries. International Market Review, 34(4), 536-558.

Fill, C. (2002). Marketing communications: contexts, strategies and applications, $3^{\text {rd }}$ Ed. London: Prentice-Hall.

Fletcher, W. (1992). A glittering haze: Strategic advertising in the 1990s. Bristol: NCT Publication. Harvey, D. (2005). A brief history of neoliberalism. Oxford: Oxford University Press.

Healey, M. (2008). What is branding? UK: RotoVision.

Jefkins, F. \& Yadin, D. (2000). Advertising. $4^{\text {th }}$ Ed. Prentice Hall: Financial Times Press.

Kabani, S., \& Brogan, C. (2010). The zen of social media marketing. Dallas, TX: Benbella Books. Kapferer, N. (2008). The new strategic brand management. Paris: Les Editions d'Organisation.

Khan, B. M., Shahid, S. A, \& Akhtar, A. (2009). Role of trust: Brand equity. SCMS Journal of Indian Management, 6(2), 12-22.

Kietzmann, J.H., Hermkens, K., McCarthy, I.P., Silvestre, B.S., 2011. Social media? get serious! understanding the functional building blocks of social media. Business Horizons 54, 241-251.

Kietzmann, J. H., Silvestre, B. S., McCarthy, I. P., \& Pitt, L. (2012). Unpacking the social media phenomenon: Towards a research agenda. Journal of Public Affairs, 2(2), 109-119.

Kim A.J \& Ko, E. (2012). Do social media marketing activities enhance customer equity? An empirical study of luxury fashion brand. Journal of Business Research, 65(10),1480-1486.

Kotler, P. (1998). Marketing management: analysis, planning, implementation and control. Upper Saddle River: Pearson Education Inc.

Kotler, P., \& Armstrong, P. (2010). Principles of marketing. Upper Saddle River: Pearson Education Inc.

Kotler, P., \& Pfoertsch, P. (2006). B2B brand management. Heidelberg: Springer.

Kronberger, M. (2010). Brand society. Cambridge: Cambridge University Press.

Lee, M. S. W., Conroy, D. \& Motion, J. (2012). Brand avoidance, genetic modification, and brandlessness. Australasian Marketing Journal, 20(4), 297-302.

Li, C., and J. Bernoff (2011). Groundswell: Winning in a world transformed by social technologies. Boston M.A.: Harvard Business Review Press.

Lury, C. (2011). Consumer culture. $2^{\text {nd }}$ Ed. New Brunswick: Rutgers University Press. 
Makasi, A., Govender, K.K., \& Rukweza, C. (2014). Building brand equity through advertising. Mediterranean Journal of Social Sciences, 5 (20), 2613-2624.

Malik, M., E., Naeem, B., \& Munawar, M. (2012). Brand image: past, present and future. Journal of Basic and Applied Scientific Research, 2 (12), 13069-13075.

Mangold, W.G. \& Faulds, D.J. (2009). Social media: The new hybrid element of the promotion mix. Business Horizons, 52 (4), 357-365.

Manovich, L. (2001). The language of new media. Cambridge: MIT Press.

Martinez, J. (2019). How Social media impacts a brand: The stats. Redefine Marketing Group. Available at https://www.redefineyourmarketing.com/blog/how-social-media-impactsa-brand-the-stats

McClintock, A. (1994). Soft-soaping empire: commodity, racism and imperial advertising. In G. Robertson et.al. (Eds), Travelers' Tales: Narratives of Home and Displacement (pp.132155). London: Routledge.

Mehta, A. (2000). Advertising attitudes and advertising effectives. Journal of Advertising Research, 40 (3), 67-72.

Mohsin, M. (2009). Encyclopedia of brand equity management. Mumbai [India]: Himalaya Pub. House.

Moreira A.C., Fortes, N. \& Santiago, R. (2017). Influence of sensory stimuli and brand experience, brand equity and purchase intention. Journal of Business, Economic and Management, 18(1), 68-83.

Neti, S. (2011). Social media and its role in marketing. International Journal of Enterprise Computing and Business Systems, 1 (2), 1-15.

Nielsen Media (2011). How social media impacts brand marketing. Nielsen. Available at, https:/www.nielsen.com/us/en/insights/article/2011/how-social-media-impacts-brandmarketing/

Pavitt, C. (2000). Answering questions requesting scientific explanations for communication. Communication Theory, 10(4), 379-404.

Pozin, I. (2014). Small business expert: answers to your five biggest social media branding questions. Forbes. [Ref. 19 Dec. 2020]. Available at: http://www.forbes.com/sites/ ilyapozin/2014/11/07/small-business-expert-an-swers-to-your-five-biggest-social-mediabranding-questions/

Romani, S., Grappi, S., \& Dalli, D. (2012). Emotions that drive consumers away from brands: measuring negative emotions toward brands and their behavioral effects. International Journal of Research in Marketing, 29 (1), 55-67.

Soo-Hyun Jun (2020). The effects of perceived risk, brand credibility and past experience on purchase intention in the Airbnb context. Sustainability, 12, 1-17.

Vinerean, S., Cetina, J., Dumitrescu, L., \& Tichindelean, M. (2013). The effects of social media marketing on online consumer behavior. International Journal of Business and Management, $8(14), 66-79$.

Wang, J. (2008). Brand new China: Advertising, media and commercial culture. Cambridge, MA: Harvard University Press.

Yasri Yasri, Peringki Susanto, Mohammad Enamul Hoque \& Mia Ayu Gusti (2020). Price perception and price appearance on repurchase intention of gen $\mathrm{Y}$ : Do brand experience and brand preference mediate? Heliyon, 6 (11), 1-8. 
Yoo, B., Donthu, N, \& Lee, S. (2000). An examination of selected marketing mix elements and brand equity. Journal of the Academy of Marketing Science, 28 (2), 195-211.

Yusuf, A., Fatih, G., \& Hayrettin, Z. (2013). Examining perceived risk and its influence on attitudes: a study on. private label consumers in Turkey. Asian Social Science, 9 (4), 158-166.

Zeithaml, V.A. (1988). Consumer perceptions of price, quality, and value: a means-end model and synthesis of evidence. Journal of Marketing, 52, 2-22. 